\title{
UTILIZATION OF GOATS' MILK IN EDAM-LIKE CHEESE MAKING
}

\author{
Metry, Wedad A. ${ }^{1}$, M.A. El- Batawy ${ }^{1}$, M.A. Zedan $^{2}$ \& H.S.M. El-Tawel ${ }^{2}$ \\ ${ }^{1}$ Dairy Science Dept., Fac. of Agric.,t Fayoum, Cairo University, Egypt . \\ ${ }^{2}$ Food Technology Research Institute, Agric. Res. Center, Giza, Egypt.
}

\begin{abstract}
Edam-like cheese was made from pasteurized standardized cows', goats' milk and their mixture (1:1). The resultant cheeses were ripened for 90 days at $12 \pm 2^{\circ} \mathrm{C}$ and $85-90 \%$ relative humidity. Samples of cheeses were periodically analyzed, for chemical composition, ripening indices, acid - base titration, total biogenic amines and organoleptic properties. Yield of cows 'milk Edam cheese was slightly higher than goats' milk cheese or their mixture (1:1) milk cheese. Moisture content, titratable acidity and area of hysteresis loop were higher in cows' milk-cheese than that of goats' milk or mixed milk-cheeses, whereas; fat; salt content; fatty acid composition; total soluble and non protein nitrogen and total biogenic amines were lower.

Organoleptic taste panel evaluation was the highest for cows' milk Edam - like cheese and the lowest for goats' milk cheese. The mixing of cows' milk with goats' milk (at the ratio of 1: 1) improved the quality of the resultant cheese. Statistically, in all treatments no significant differences between 60 and 90 days of ripening period were found in the organoleptic properties, so the 60 days age is economically preferred.
\end{abstract}

Keywords: Edam-like cheese, goats' milk, biogenic amines, hysteresis, fatty acid pattern, sensory evaluation

\section{INTRODUCTION}

It is well known that goats are early regarded as a source of milk production. The world production of goats' milk is approximately 12.4 million tons, which represents about $2.1 \%$ of the total milk production from all other milking animal species (IDF, 2000). Most of goats' milk is not well utilized for dairyindustry. Since the Second World War, a great interest had been arisen to develop goats for milk production all over the World. In Egypt, increased attention has been directed towards goats' milk production because of its lower cost compared with cows' milk production and it's chemical similarity to cows' milk. The annual goats' milk production in 1998 was 116000 tons (F.B.S. 1998) and increased to 126000 tons in 2002 (F.B.S. 2002). Many famous varieties of cheese are made from goats' milk for example in France; the most expensive cheeses after Roquefort are goats' milk cheese. Also in Italy, Spain and Swiss goats' milk cheese are highly appreciated. In Egypt goats' milk dairy products are not highly accepted.

Edam cheese is made in Edam Village, Holland North of Hoofddorp; it is one of the semi-hard cheese variety. Varieties of Edam are produced in Germany, Finland, Spain, Portugal (there it's called "flamengo"), and also in South and North America. Edam cheese is proved great acceptability by the Egyptian consumers due to its attractive characteristic flavour, as well its round balledshape.

The most acceptable Edam cheese of high quality is usually made from very clean cows' milk. In Egypt there is short supply of the suitable milk production for making this type of cheese. However, trials have been made for using buffaloes' milk in semi-hard cheese making (Fikry, 1978, Ismail, 1995). Also; there were some attempts to use goats' milk in making some accepted dairy products, but few trials were carried out to use it in making of Edam cheese.

Therefore, this work was carried out as an attempt to utilize the goats' milk in processing Edam-like cheese accepted by Egyptian consumers.

\section{MATERIALS AND METHODS}

\section{Materials :}

Fresh Friessien cows' and Demuscus goats' milk were obtained from the dairy herds of 
Sakha Experimental Station, Kafr El-Sheikh province Animal Production Research Institute, Ministry of Agriculture (chemical composition of both milks and their mixture are given in Table (1).

Calf powder rennet (HALA) and mesophilic mixed aromatic culture type LD (LDculture CH-N22) containing Lactococcus lactis subsp. cremoris, Lactococcus lactis subsp. lactis, Leuconostoc mesenteroides subsp. cremoris and Lactococcus lactis subsp. diacetylactis, were obtained from $\mathrm{Chr}$. Hansen Laboratories (Denmark).

Commercial edible grade sodium chloride was obtained from El-Nasr Company for salt, Alexandria, Egypt.

\section{Methods:}

\section{Cheese making}

Thirty kilograms of fresh cows' milk, goats' milk or their mixture (1:1) were standardized, pasteurized by HTST method (VICARB- France) and manufactured Edam-like cheese in dairy processing pilot plant, Dairy Department, Faculty of Agriculture, Fayoum branch, Cairo University according to the method described by Scott ( 1998 ) as illustrated in Figure (1). Samples of fresh and ripened cheese were taken at $0,15,30,60$ and 90 days for chemical analysis.

\section{Chemical analysis}

(a) Milk samples: were tested for total acidity, total solids, fat content, total nitrogen and casein nitrogen as mentioned in Ling (1963).

(b) Cheese: Titratable acidity, fat, moisture, salt, total nitrogen (TN), water soluble nitrogen (WSN) and non protein nitrogen (NPN) were determined as mentioned in Ling (1963). Total volatile fatty acids (TVFA) were determined by the direct distillation method as described by Kosikowski (1978), values were expressed as $\mathrm{ml}(0.1 \mathrm{~N}) \mathrm{NaOH} / 100 \mathrm{~g}$. cheese.

Free fatty acids (FFA) were extracted from cheese samples using a methanol- chloroform mixture 2:1 (v/v). The solvent was evaporated using a rotary evaporator. Preparative Thin Layer Chromatography (TLC) was applied to separate the free fatty acids fraction of the sample as described by Stahli (1965). Fatty acids were converted to the corresponding methyl esters using methanol zinc chloride and zinc dust according to Shahin (1977). The determination of resulted fatty acids methyl esters was carried out using a Gas Liquid Chromatograph, type Hewlett-Packard 5840A, with double flame ionization detector and with multi level temperature programmer provided with a Hp5840A terminal, column used was a 6 feet stainless steel packed with $10 \%$ V.C.W 928 on chromosorb W.A.M. DMCS treated, 80-100 mesh (Hewlett Packard).Carrier gas used was nitrogen. The conditions were as follows: length of column, 6 feet, with internal diameter $4 / 8$ inches, programming temper-ature 140 $300^{\circ} \mathrm{C} \quad\left(8^{\circ} \mathrm{C} / \mathrm{min}\right)$. Detector temper-ature $300^{\circ} \mathrm{C}$ injection port temperature $230^{\circ} \mathrm{C}$. Carrier gas flow rate (N2) $40 \mathrm{ml} / \mathrm{min}$. Hydrogen flow rate $40 \mathrm{ml} / \mathrm{min}$. Air flow $300 \mathrm{ml} / \mathrm{min}$.

Biogenic amines were extracted from cheese samples as described by Ayesh et al. (1995) and determined according to Naguib et al. (1995).

The acid-base titration curves (hysteresis) of cheese samples were determined by titration as described by Awad (2001).

\section{Evaluation of organoleptic properties}

The organoleptic properties of Edam-like cheese were assessed by a panel of 10 members of the Dairy and Food Science \& Technology Department, Faculty of Agriculture, Fayoum. Colour and appearance were evaluated of 15 points, for body and texture out of 35 points, and for flavour out of 50 points.

The scoring was carried out simultaneously with chemical analysis of the samples at different ages of cheese ripening $(15,30,60$, and 90 days).

Experiments of cheese processing were repeated in triplicates, while chemical and organoleptic analyses were in duplicates and mathematic average results were tabulated.

Data of sensory evaluation were subjected to analysis of variance using SPSS (1998). Means having a significant $\mathrm{F}$-test $(\mathrm{P} \leq 0.01)$ were compared using Duncan's multiple range test (Duncan, 1955). 


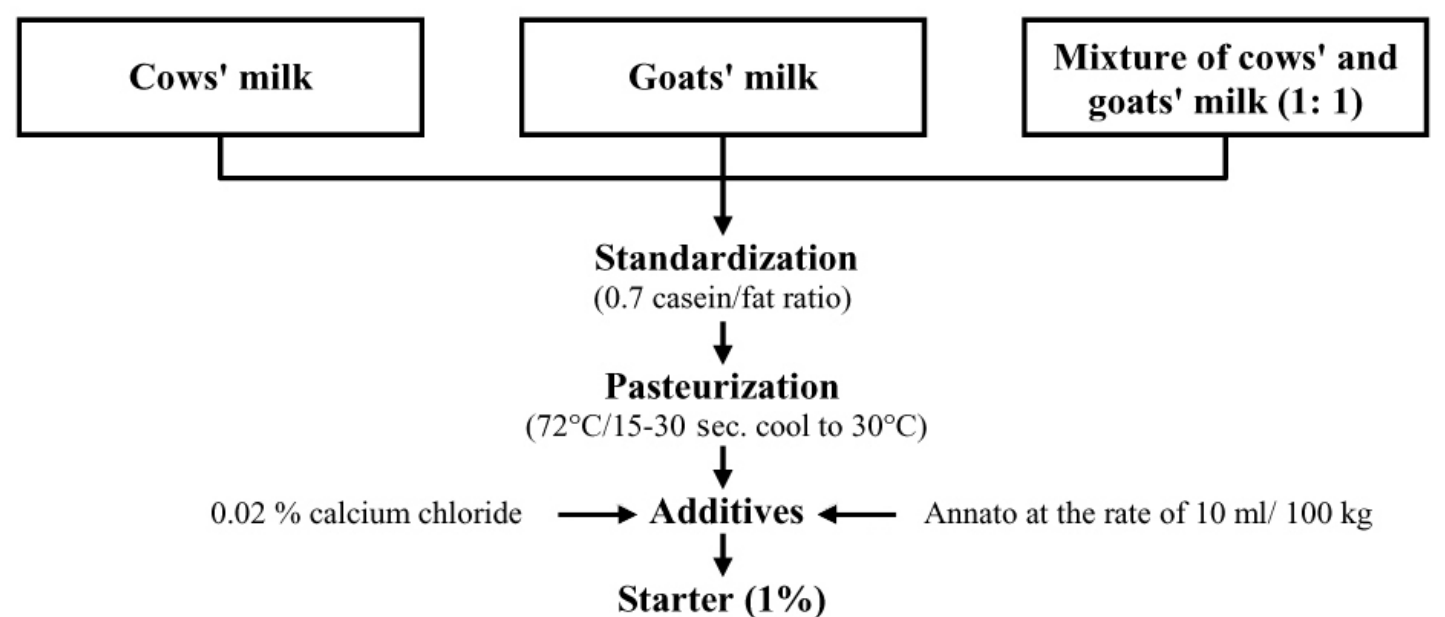

Added at $30^{\circ} \mathrm{C}$ and ripened for $20-30 \mathrm{~min}$. Acidity $0.17 \%$

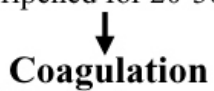

$3.0 \mathrm{~g}$ powder rennet $/ 100 \mathrm{~kg}$ of cheese milk at $30-31^{\circ} \mathrm{C}$ curd is firm to cut in $30 \mathrm{~min}$.

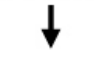

\section{Cutting}

cut into $1 \mathrm{~cm}$ cubes (using the American knives) and rest for $5 \mathrm{~min}$.

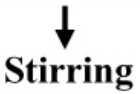

for $15-30 \mathrm{~min}$. Settle curd and drain off third to half of whey.

\section{Scalding}

was accomplished by raising the whey temperature gradually to $37^{\circ} \mathrm{C}$

with continuous stirring until curd is firm and $\mathrm{pH}$ of whey

$$
\text { is } 6.0-6.1 \text { (approximately } 40 \mathrm{~min} \text { ) }
$$

Whey drainage

curd is drawn to the center of the vat and allowed to settle. Most of the whey is run off.

\section{Moulding}

The curd was then filled in special plastic shaped moulds (two pieces, spherical shape,

$10 \mathrm{~cm}$ in depth and $15 \mathrm{~cm}$ in diameter) with cloth and put top piece on curd ready for press

\section{$\stackrel{\downarrow}{\downarrow}$}

The cheeses are lightly pressed for $20 \mathrm{~min}$. Followed by pressing at $4-6 \mathrm{~kg} / \mathrm{cm} 2$ for $3 \mathrm{hr}$.

During pressing the cheese is turned in the mould and re-pressed over night. Temp. maintained at $17 \pm 2^{\circ} \mathrm{C}$.

\section{$\downarrow$ \\ Salting}

The cheeses are immersed in saturated brine at a $\mathrm{pH}$ of 5.75-5.85 for 3-4 days at $12-14^{\circ} \mathrm{C}$. After salting the green cheese was placed for 2 days in ripening room for drying and weighted.

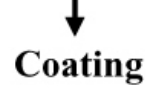

The cheese was then carefully coated with yellow plastic coat.

\section{Maturation}

Resultant cheeses were then kept in the ripening room at $12 \pm 2^{\circ} \mathrm{C}$ and $90 \%$ relative humidity for 3 months.

Fig. 1: The processing stages of Edam-like cheese 


\section{RESULTS AND DISCUSSION Milk composition:}

Table (1) shows the chemical composition of the three types of milk utilized in the present study. To some extent the chemical composition of cows' milk is similar to goats' milk.

Table 1: Chemical composition of cows' milk, goats' milk and their mixture (1:1)

\begin{tabular}{lccc}
\hline Type of milk & $\begin{array}{c}\text { Total } \\
\text { Solids } \\
(\%)\end{array}$ & $\begin{array}{c}\text { Fat } \\
(\mathbf{\%})\end{array}$ & $\begin{array}{c}\text { Protein } \\
(\mathbf{\%})\end{array}$ \\
\hline Cows' milk & 11.89 & 3.10 & 3.00 \\
Goats' milk & 11.07 & 3.00 & 2.91 \\
$\begin{array}{l}\text { Mixture of cows' and } \\
\text { goats' milk (1:1) }\end{array}$ & 11.13 & 3.07 & 2.95 \\
\hline
\end{tabular}

\section{Cheese yield}

Results presented in Table (2) show that cows' milk had higher yield of Edam - like cheese than from goats' milk which may be due to differences in physical properties of casein in both kinds of milk particularly its water holding capacity and fat and protein retention in cheese. The yield of Edam cheese made from a mixture of cows' and goats' milk (1:1) was close to that made from cows' milk .The results also indicated that the yield of cheese decreased during ripening in all treatments, mainly due to losses in moisture content of cheese during ripening (Nasr et al., 1991, El-Neshway et al., 1995, El-Shibiny et al., 1998, El-Sisey, 2002 ).

\section{Chemical composition}

It is clear from Table (2) that the mois-ture content of cheese from all treatments under study decreased sharply during the $1^{\text {st }}$ month of ripening and then gradually thereafter. Whereas the moisture contents were 47.82 , 46.42 and $47.19 \%$ in fresh samples, it declined to $40.00,39.92$ and $39.95 \%$ after 3 months of ripening for Edam-like cheese made from cows', goats' milk and their mixture, respectively. Similar results were reported by El-Shibiny et al., 1998, El-Sheikh et al., 1999

Table 2: Changes in the yield and chemical composition of Edam-like cheese made from different types of milk during ripening

\begin{tabular}{|c|c|c|c|c|c|c|}
\hline \multirow{2}{*}{ Properties } & \multirow{2}{*}{$\begin{array}{c}\text { Milk } \\
\text { type }\end{array}$} & \multicolumn{5}{|c|}{ Ripening period (days) } \\
\hline & & Fresh & 15 & 30 & 60 & 90 \\
\hline \multirow{3}{*}{ Yield (\%) } & $\mathrm{C}$ & 11.98 & 11.10 & 10.38 & 10.10 & 10.02 \\
\hline & $\mathrm{G}$ & 11.46 & 10.38 & 10.12 & 9.88 & 9.86 \\
\hline & M & 11.78 & 11.00 & 10.33 & 10.04 & 9.97 \\
\hline \multirow{3}{*}{ Moisture (\%) } & $\mathrm{C}$ & 47.82 & 44.30 & 41.43 & 40.30 & 40.00 \\
\hline & G & 46.42 & 43.87 & 41.00 & 40.01 & 39.92 \\
\hline & M & 47.19 & 47.07 & 41.40 & 40.23 & 39.95 \\
\hline \multirow{3}{*}{ Salt (\%) } & $\mathrm{C}$ & 1.67 & 1.94 & 2.54 & 3.18 & 3.34 \\
\hline & $\mathrm{G}$ & 1.78 & 2.14 & 2.82 & 3.31 & 3.56 \\
\hline & M & 1.73 & 2.03 & 2.76 & 3.23 & 3.34 \\
\hline \multirow{3}{*}{ Salt / Moisture (\%) } & $\mathrm{C}$ & 3.49 & 4.38 & 6.13 & 7.89 & 8.35 \\
\hline & $\mathrm{G}$ & 3.83 & 4.88 & 6.88 & 8.27 & 8.92 \\
\hline & M & 3.67 & 4.29 & 6.67 & 8.03 & 8.36 \\
\hline \multirow{3}{*}{ Fat $(\%)$} & $\mathrm{C}$ & 22.88 & 24.63 & 25.95 & 26.55 & 27.44 \\
\hline & $\mathrm{G}$ & 23.25 & 25.01 & 26.31 & 27.19 & 28.01 \\
\hline & M & 23.05 & 24.82 & 26.02 & 26.85 & 27.81 \\
\hline \multirow{3}{*}{ Fat/ Dry matter $(\%)$} & $\mathrm{C}$ & 43.85 & 44.22 & 44.31 & 44.47 & 45.73 \\
\hline & G & 43.39 & 44.55 & 44.59 & 45.32 & 46.62 \\
\hline & M & 42.62 & 44.38 & 44.40 & 44.92 & 46.31 \\
\hline \multirow{3}{*}{ Titratable Acidity (\%) } & $\mathrm{C}$ & 1.01 & 1.17 & 1.35 & 1.86 & 1.92 \\
\hline & G & 0.99 & 1.13 & 1.23 & 1.68 & 1.86 \\
\hline & M & 1.03 & 1.23 & 1.35 & 1.73 & 1.88 \\
\hline \multirow{3}{*}{ TVFA* } & $\mathrm{C}$ & 9.00 & 13.00 & 21.00 & 30 & 39 \\
\hline & $\mathrm{G}$ & 12.00 & 18.00 & 25.00 & 34 & 42 \\
\hline & $\mathrm{M}$ & 11.00 & 16.00 & 23.00 & 31 & 40 \\
\hline
\end{tabular}

C: Cows'milk, 
and El-Sisey 2002. Edam-like cheese made from cows' milk contained higher moisture content than that from goats' milk which is parallel to cheese yield .Edam-like cheese made from mixed cows' and goats' milk had moisture content close to that cheese made from cows' milk

Table (2) shows the fat contents ranged between $22.88-23.05 \%$, whereas salt content were $1.67-1.73$ in fresh cheese samples. It is clear from these results that the salt/moisture percentage and fat content of Edam-like cheese from different milks increased gradually during ripening. This apparent increase is due to the loss of moisture content during ripening. These results are in agreement with those reported by Nasr et al. (1992), ElShibiny et al. (1998), El-Sheikh et al. (1999) and El-Sisey (2002). All the analyzed cheeses conformed the Egyptian Standards (1998) for the fat/dry matter mainly $45 \%$ of this type of cheese all through the ripening period. Table (2), also shows that goats' milk cheese had lower titratable acidity (TA) than cows' milk cheese or that made from their mixture, throughout ripening period which can be attributed to its lower moisture and higher salt content. In all treatments, the cheese TA increased as ripening period progressed. These results are in agreement with those of Nasr et al. (1991) and El-Sisey (2002). From Table (3), it could be seen that goats' milk cheese contained higher total nitrogen than either cheese from cows' milk or its mixture with goats' milk during cheese ripening. This may be due to the lower moisture content of goats' milk cheese than that of the other treatments. This is in agreement with the results obtained by El-Abd et al. (1992). The TN of all cheeses markedly increased as ripening period progressed. Similar trend of total nitrogen in Edam-like cheese was reported by Nasr et al. (1992), El-Sheikh et al. (1999) and El Sisey (2002). Also water soluble nitrogen (WSN \%) was the highest in goats' milk cheese, followed by mixed goats' and cows' milk cheese (Table 3). Cows' milk Edam-like cheese showed the lowest WSN and NPN contents all through the ripening period. The higher WSN content of goats' milk cheese, may be due to more proteolysis ability of goats' milk protein and /or its high content of proteases (Rao, 1990).

\section{Ripening indices}

Water soluble nitrogen/total nitrogen (WSN/TN\%) and non protein nitrogen/total nitrogen (NPN/TN\%) : Progress of ripening is expressed by WSN/TN (\%) and NPN/TN (\%) values shown in Table (3). The use of goats' milk either alone or mixed with cows' milk in Edam - like cheese making gave higher WSN/TN and NPN/TN which indicate to more progress in cheese ripening .Similar results were reported for Ras cheese made by goats' milk as reported by El-Abd et al. (1992) and El-Batawy et al. (1992). In all treatments the WSN/TN\% markedly increased during the first 60 days, followed by slow increase thereafter.

Total volatile fatty acid content (TVFA): Results presented in Table (2) reveal that the TVFA followed similar trends of changes during ripening to those of $\mathrm{WSN} / \mathrm{TN} \%$ and NPN/TN\% (Table 3). TVFA gradually increased in all cheeses throughout the ripening. These findings are in agreement with those reported by Nasr et al., (1992), Zaki \& Salem (1992) and El-Sisey (2002). Cheese made from goats' milk either alone or mixed with cows' milk had higher TVFA than cheese made from cows' milk. These results might be due to the lower fat globules size in goats' milk that would increase lipolysis in cheese than cows' milk one (McCullough, 2003), which indicated that the use of goats' milk may be accelerated the ripening of Edam cheese. Similar results were reported for Ras cheese by El-Abd et al. (1992).

Free fatty acid (FFA) pattern of cheese : The FFA patterns of fresh and 90 days old Edam-like cheese made from different milks are given in Table (4). Edam cheese from goats' milk was characterized by higher percentage of $\mathrm{C} 8, \mathrm{C} 10, \mathrm{C} 12$,C18 and C18:2 FFA, than its counterpart from cows' milk McCullough (2003) and Ramos et al. (1988) reported that the presence of higher level of C10 in goats' milk fat than cows' milk fat which may explain our results. Goats' milk cheese had a higher percentage of short chain free fatty acids followed by cheese made by mixture of goats' and cows' milk cheese, whereas cows' milk cheese showed the lowest level of short chain free fatty acids for fresh and 90 days old cheese samples of ripening. Intermediate and long chain free fatty acids were higher in cows' milk cheese than that for 
goats' milk cheese. These results are in agreement with those reported by Hiekal et al. (1992) for Ras cheese and El-Demerdash (1996) for Gouda cheese. Cows' milk cheese contained the highest level of odd carbon number fatty acids followed by mixed goats' and cows' milk cheese, whereas goats' milk cheese contained the lowest level of such fatty acids. Similar results were reported for Gouda cheese by El-Demerdash (1996).

Table 3: Nitrogen content of Edam-like cheese during ripening as affected by types of milk

\begin{tabular}{|c|c|c|c|c|c|c|}
\hline \multirow{2}{*}{ Properties $(\%)$} & \multirow{2}{*}{$\begin{array}{l}\text { Milk } \\
\text { type }\end{array}$} & \multicolumn{5}{|c|}{ Ripening period (days) } \\
\hline & & Fresh & 15 & 30 & 60 & 90 \\
\hline \multirow{4}{*}{$\mathrm{TN}$} & $\mathrm{C}$ & 3.100 & 3.450 & 3.840 & 3.980 & 4.050 \\
\hline & G & 3.360 & 3.680 & 3.980 & 4.040 & 4.110 \\
\hline & M & 3.220 & 3.520 & 3.880 & 4.000 & 4.070 \\
\hline & $\mathrm{C}$ & 0.239 & 0.321 & 0.379 & 0.451 & 0.528 \\
\hline \multirow[t]{2}{*}{ WSN } & $\mathrm{G}$ & 0.319 & 0.375 & 0.413 & 0.526 & 0.629 \\
\hline & M & 0.271 & 0.343 & 0.399 & 0.512 & 0.563 \\
\hline \multirow{4}{*}{ NPN } & $\mathrm{C}$ & 0.065 & 0.133 & 0.173 & 0.194 & 0.260 \\
\hline & G & 0.099 & 0.162 & 0.192 & 0.230 & 0.293 \\
\hline & M & 0.073 & 0.146 & 0.182 & 0.215 & 0.285 \\
\hline & $\mathrm{C}$ & 7.710 & 9.300 & 9.870 & 11.330 & 13.040 \\
\hline \multirow[t]{2}{*}{$\mathrm{SN} / \mathrm{TN}$} & G & 9.490 & 10.190 & 10.380 & 13.020 & 15.300 \\
\hline & M & 8.420 & 9.740 & 10.280 & 12.800 & 13.830 \\
\hline \multirow{3}{*}{ NPN/TN } & $\mathrm{C}$ & 2.100 & 3.860 & 4.510 & 4.870 & 6.420 \\
\hline & G & 2.950 & 4.400 & 4.820 & 5.690 & 7.130 \\
\hline & M & 2.270 & 4.150 & 4.700 & 5.380 & 7.000 \\
\hline
\end{tabular}

Table 4: Changes in fatty acid (\%) pattern of Edam-like cheese as affected by the types of milk for fresh and old cheese (90 days)

\begin{tabular}{lrrrrrr}
\hline \multirow{2}{*}{ Fatty acids } & \multicolumn{2}{c}{ Cows' cheese } & \multicolumn{2}{c}{ Goats' cheese } & \multicolumn{2}{c}{ C:G (1:1) cheese } \\
\cline { 2 - 7 } & Fresh & 90 days & Fresh & 90 days & Fresh & 90 days \\
\hline $\mathrm{C}_{4}$ & 1.44 & 1.58 & 1.27 & 1.62 & 1.01 & 1.11 \\
$\mathrm{C}_{6}$ & 0.75 & 0.78 & 0.65 & 0.79 & 0.35 & 0.44 \\
$\mathrm{C}_{8}$ & 1.38 & 1.42 & 2.38 & 3.08 & 1.98 & 2.01 \\
$\mathrm{C}_{10}$ & 2.95 & 2.68 & 9.13 & 10.13 & 5.43 & 6.43 \\
Total short chain $_{\mathrm{C}_{12}}$ & 6.52 & 6.46 & 13.43 & 15.62 & 8.77 & 9.99 \\
$\mathrm{C}_{14}$ & 3.16 & 2.8 & 3.57 & 4.30 & 4.41 & 3.61 \\
$\mathrm{C}_{14: 1}$ & 10.56 & 9.73 & 8.78 & 8.82 & 10.16 & 9.30 \\
$\mathrm{C}_{15}$ & 2.44 & 0.92 & 1.52 & 0.32 & 1.86 & 0.88 \\
$\mathrm{C}_{16}$ iso & 1.98 & 1.32 & 1.82 & 0.65 & 1.65 & 1.10 \\
$\mathrm{C}_{16}$ & 1.65 & 1.81 & --- & 0.46 & 0.86 & 2.01 \\
$\mathrm{C}_{16: 1}$ & 25.85 & 26.90 & 27.73 & 26.55 & 24.09 & 25.13 \\
Total intermediate chain & 1.28 & 1.33 & 0.93 & 0.45 & 1.10 & 0.86 \\
$\mathrm{C}_{17}$ & 46.92 & 44.81 & 44.35 & 41.55 & 44.13 & 42.89 \\
$\mathrm{C}_{17: 1}$ & 1.73 & 1.62 & 1.19 & 1.32 & 0.91 & 0.98 \\
$\mathrm{C}_{18}$ & 2.80 & 0.82 & 0.61 & 0.23 & 1.55 & 0.45 \\
$\mathrm{C}_{18: 1}$ & 10.64 & 11.02 & 13.61 & 13.55 & 14.81 & 16.13 \\
$\mathrm{C}_{18: 2}$ & 21.51 & 31.17 & 22.21 & 21.65 & 21.99 & 24.34 \\
$\mathrm{C}_{18: 3}$ & 4.35 & 2.61 & 4.20 & 6.08 & 4.11 & 4.70 \\
$\mathrm{C}_{20}$ & 5.53 & 0.86 & 0.40 & --- & 3.31 & 0.39 \\
Total long chain & --- & 0.65 & --- & -- & 0.33 & 0.13 \\
Odd number & 46.56 & 48.75 & 42.22 & 42.83 & 47.01 & 47.12 \\
Even number & 6.51 & 3.76 & 3.62 & 2.2 & 4.11 & 2.52 \\
\hline & 93.49 & 96.24 & 96.38 & 97.80 & 95.89 & 97.47 \\
\hline
\end{tabular}




\section{Ripening of Edam cheese as indicated by acid- base titration (hysteresis)}

The obtained results for potentiometric titration of Edam-like cheese during ripening as affected by the type of milk are presented in Fig. (2).The total consumption of milliliters titrants are considered as a degree of protonation $\alpha=1.0$. The area of hysteresis loop is given by $\phi \alpha \mathrm{dpH}$, which was greater for cows' milk cheese than that of mixed cows' and goats' milk cheese, whereas, the area of hysteresis loop of goats' milk cheese was the lowest one. The integral $\phi \alpha d p H$ value was 0.464 for fresh cows' milk cheese, whereas, it was 0.335 for fresh goats' milk cheese. These data indicate differences in the casein composition, particle size of the casein micelles and clotting behavior of cows' and goats' milk (Ganguli, 1973). The data indicate that the degrees of hysteresis ( $(\mathrm{ddpH})$ values of cheeses were gradually decreased as the ripening progressed for all treatments. Furthermore, it can be noticed from the same figure that the rate of decrease in the hysteresis area (фadpH.) was higher in goats' milk cheese than that in cows' milk cheese. This may be due to more proteolysis ability of goats' milk protein. Similar trends in the degree of hysteresis ( $ф \alpha \mathrm{dpH}$.$) of goats' and cows' milk$ white cheese were reported by Shendy (1989). Similar results were reported for Ras cheese by Kandeal et al. (1990) and Shendy et al. (1993). Also, it is evident from that the $\mathrm{pKa}$ values of cheese from all treatments were shifted during ripening to the base side (from 5.60 to 6.20 ). This could be attributed to the increase of the basic groups as a result of some decomposition products during cheese ripening. These results agree with those reported for white cheese by ElShobery (1988) and Awad (2001).

From the aforementioned results, it can be concluded that the acid-base titration technique as a simple and accurate analytical method could be quite informative for Edamlike cheese during ripening. The integral $\phi \alpha \mathrm{dpH}$ of cheese during ripening gives an important indication to the extent of protein breakdown in cheese caused by milk clotting enzymes, contaminated micro-organisms and starter proteases.

\section{Biogenic amine content}

Figure (3) shows the content of tryptamine, $\beta$-phenol, putrescine, cadaverine, histamine and tyramine in Edam-like cheese made from cows', goats' and mixture milk (1:1). Results show the absence of tryptamine from all Edam-like cheese samples. This can be explained by the low tryptophane content of casein and hence low precursor content in cheese (Joosten, 1987), similar results were obtained in Ras cheese (obtained from commercial sources in Cairo randomly) by Tawfik et al., (1992). The total biogenic amines followed similar trend of changes to those of WSN/TN. Similar result was reported by Mehanna et al., (1989) and Rodriguez et al. (2002) who found that WSN/TN and the levels of these amines were positively correlated, suggesting that extensive proteolysis, before or during the ripening process, is one of the critical factors of the formation of these amines throughout cheese making. The histamine content was found to be 2.20, 5.70 and $4.10 \mathrm{mg} / \mathrm{Kg}$., whereas, tyramine content was found to be $6.00,16.70$ and $13.0 \mathrm{mg} / \mathrm{Kg}$ and cadaverine showed 23.0, 49.5 and 32.4 $\mathrm{mg} / \mathrm{Kg}$ for Edam cheese made from cows' milk, goats' milk and their mixture, respectively. Goats' milk cheese had a higher content of tyramine, histamine, cadaverine and total biogenic amines than cows' milk cheese or that made from their (1:1) mixture. The excessive proteolysis in goats' milk cheese and richness of goats' casein in the corresponding amino acid contents may be responsible for its high content of biogenic amines. Total biogenic amine content in Edam-like cheese from all treatments ranged from 43.4 to $102.50 \mathrm{mg} / \mathrm{Kg}$. Similar results were obtained by Mehanna et al., 1989 for 5 types of Egyptian cheeses (Domiati, Tallaga, Karish, Roquefort and Ras cheese). However, Edamlike cheese made from all treatments showed values for total biogenic amines lower than the permissible limits (Taylor, 1985). 
Cows'Milk
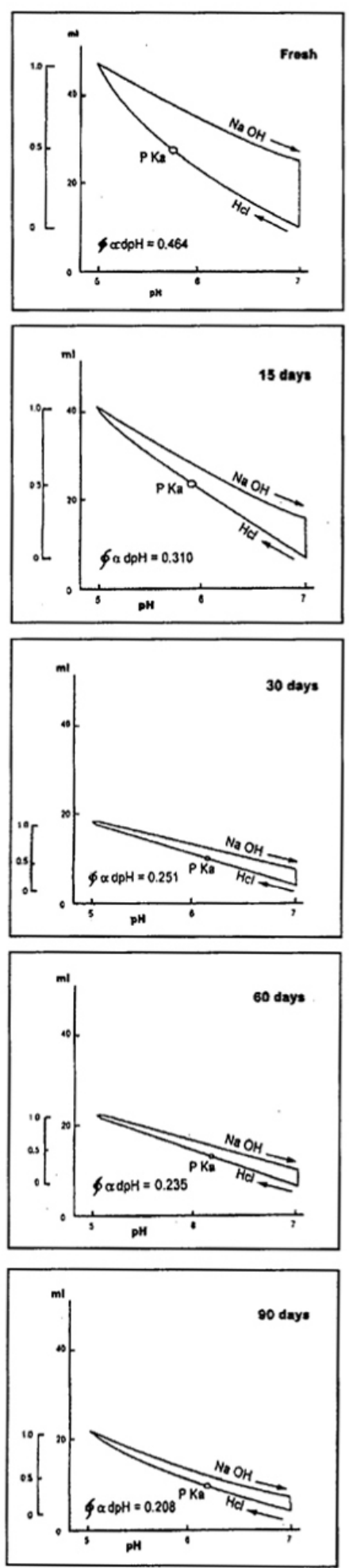

Goats 'Milk
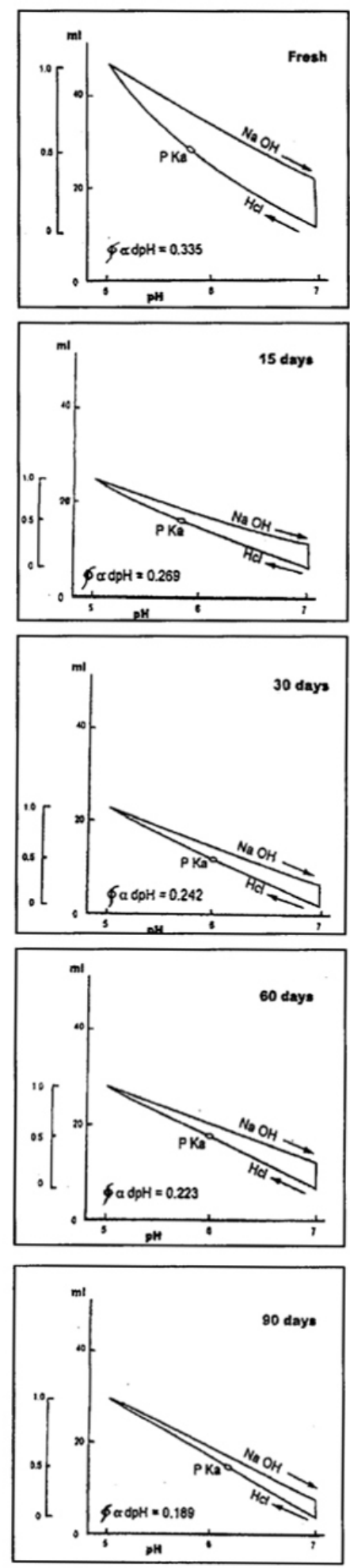

Cows': Goats 'Milk 1:1
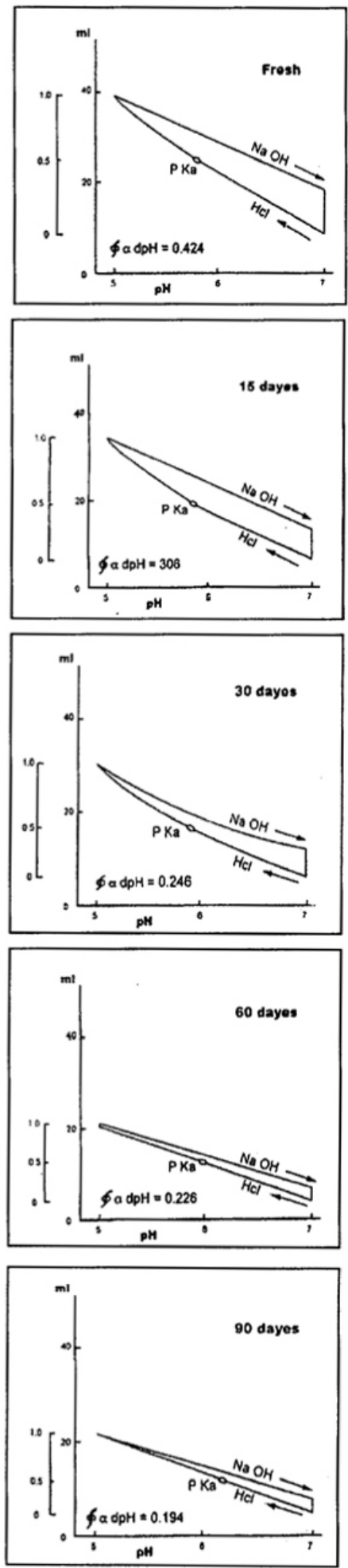

Fig. 2: Changes in the degree of hysteresis $(\phi \alpha \mathrm{dpH})$ of Edam-like cheese made from different kinds of milk during ripening 


\section{$\square$ Cows (C) $\quad \square$ Goats (G) $\quad \square$ Mixture of $(C+G)$}

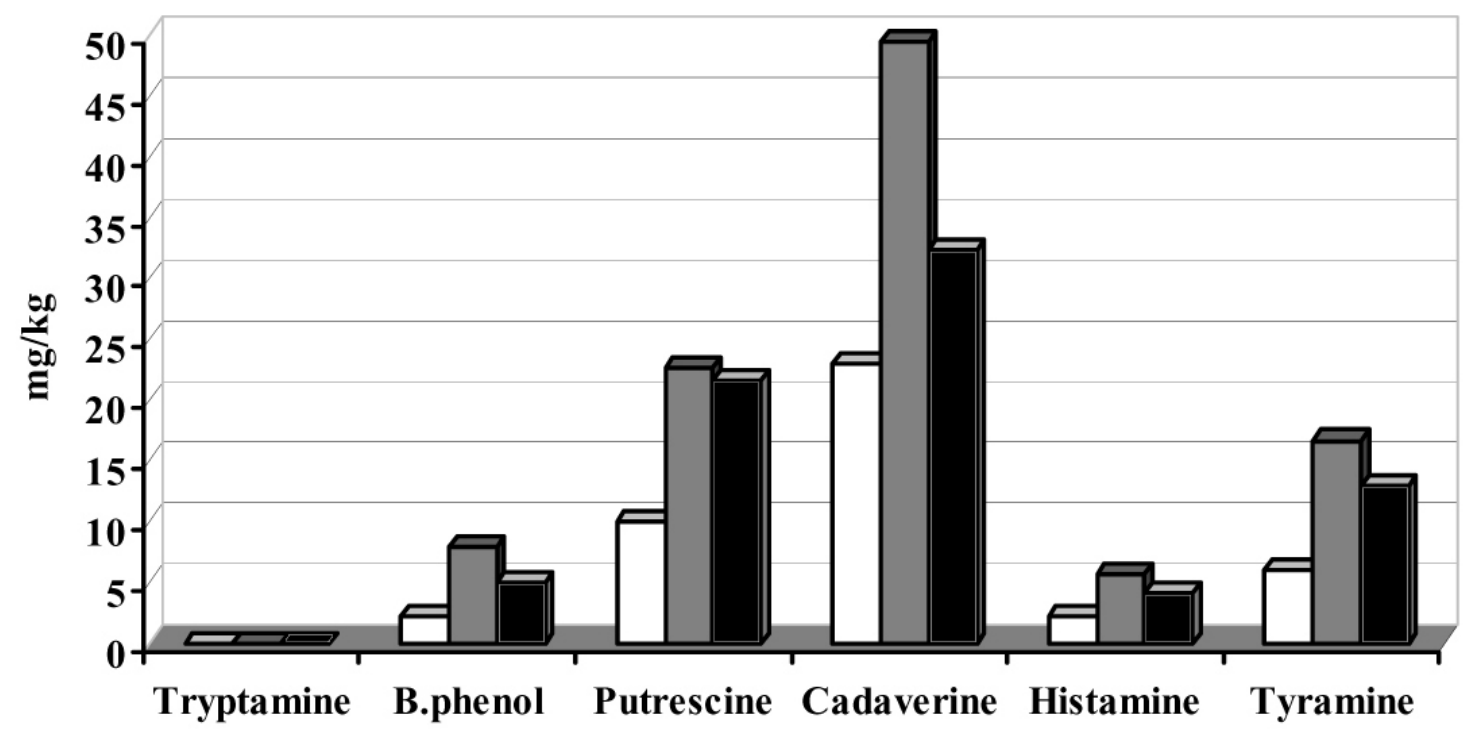

Biogenic amines

Fig. 3: Biogenic amine content of Edam-like cheese from cows', goats' milk and their mixture (1:1) at the age of 90 days.

\section{Organoleptic properties}

Typical Edam cheese according to Egyptian standards no. $1183-1998$ is smooth, elastic, pliant, softer than Gouda, gas holes few, round to oval, very mild, not acid and clean flavour.

The organoleptic properties of Edam-like cheese made from different treatments and their corresponding scores are presented in Table (5). The scoring of cheese was carried out at 4 different stages namely 15, 30, 60 and 90 days. As ripening period progressed flavour scoring markedly increased for the three treatments under study. At the end of ripening period (90 days), the cows' cheese showed the highest scoring values $(\mathrm{P} \leq 0.01)$. Although the goats' milk cheese obtained the lowest scoring values, ripening improved the flavour. This could be due to the accumulation of volatile fatty acids and carbonyl compounds, which are essential contributors to cheese flavour. Meanwhile, these compounds masked the goaty flavour. The total scoring points were $92.43,89.03$ and 87.03 for cows', mixed and goats' milk cheese respectively. This is mainly due to that the cheese made from goats' milk was characterized by goaty flavour during ripening. Regarding milk type $\mathrm{x}$ ripening periods, it could be concluded that, Edamlike cheese can be produced with adding cows' milk to goats' milk (1:1) without any significant difference from the control (without addition) at different ripening periods as shown in Table 5. The addition of cows' milk to goats' milk (1:1) markedly improved the flavour, body and texture of the resultant cheese. Statistically, in all treatments no significant differences between 60 and 90 days of age were found in the organoleptic properties, so the 60 days age is economically preferred. 
Table 5 : Effects of milk type and ripening periods on the sensory evaluation parameters of Edam-like cheese

\begin{tabular}{|c|c|c|c|c|c|c|}
\hline \multicolumn{3}{|c|}{ Item } & \multirow{2}{*}{$\begin{array}{c}\text { Colour \& } \\
\text { Appearance (15) }\end{array}$} & \multirow{2}{*}{$\begin{array}{c}\text { Body \& } \\
\text { Texture (35) } \\
31.63 \pm 1.40^{\mathrm{a}} \\
31.24 \pm 2.62^{\mathrm{a}} \\
32.14 \pm 2.63^{\mathrm{a}}\end{array}$} & \multirow{2}{*}{$\begin{array}{c}\begin{array}{c}\text { Flavour } \\
(\mathbf{5 0 )}\end{array} \\
43.03 \pm 2.10^{\mathrm{a}} \\
38.37 \pm 1.84^{\mathrm{b}} \\
39.01 \pm 2.18^{\mathrm{b}}\end{array}$} & \multirow{2}{*}{$\begin{array}{c}\begin{array}{c}\text { Total } \\
(\mathbf{1 0 0 )}\end{array} \\
88.42 \pm 4.11^{\mathrm{a}} \\
82.23 \pm 5.12^{\mathrm{b}} \\
84.27 \pm 5.59^{\mathrm{b}}\end{array}$} \\
\hline 当突总 & & $\begin{array}{l}\mathrm{C} \\
\mathrm{G} \\
\mathrm{M}\end{array}$ & & & & \\
\hline 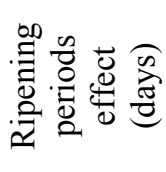 & & $\begin{array}{l}5 \\
0 \\
0 \\
0\end{array}$ & $\begin{array}{l}12.50 \pm 0.89^{\mathrm{c}} \\
12.81 \pm 0.82^{\mathrm{bc}} \\
13.34 \pm 0.88^{\mathrm{ab}} \\
14.00 \pm 0.55^{\mathrm{a}}\end{array}$ & $\begin{array}{l}29.01 \pm 2.03^{\mathrm{c}} \\
31.34 \pm 1.89^{\mathrm{b}} \\
32.82 \pm 0.78^{\mathrm{ab}} \\
33.51 \pm 0.79^{\mathrm{a}}\end{array}$ & $\begin{array}{l}37.89 \pm 2.53^{\mathrm{c}} \\
39.67 \pm 2.82^{\mathrm{b}} \\
41.01 \pm 2.39^{\mathrm{ab}} \\
41.99 \pm 2.37^{\mathrm{a}}\end{array}$ & $\begin{array}{l}79.40 \pm 5.26^{\mathrm{c}} \\
83.82 \pm 4.59^{\mathrm{b}} \\
87.18 \pm 3.25^{\mathrm{ab}} \\
89.50 \pm 2.77\end{array}$ \\
\hline \multirow{3}{*}{ 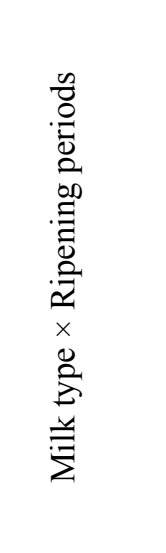 } & $\mathrm{C}$ & $\begin{array}{l}15 \\
30 \\
60 \\
90\end{array}$ & $\begin{array}{l}13.00 \pm 0.30^{\mathrm{a}} \\
13.50 \pm 0.40^{\mathrm{a}} \\
14.03 \pm 0.65^{\mathrm{a}} \\
14.47 \pm 0.61^{\mathrm{a}}\end{array}$ & $\begin{array}{l}30.03 \pm 1.12^{\mathrm{a}} \\
31.03 \pm 0.50^{\mathrm{a}} \\
32.50 \pm 0.50^{\mathrm{a}} \\
32.97 \pm 0.95^{\mathrm{a}}\end{array}$ & $\begin{array}{l}40.17 \pm 1.80^{\mathrm{a}} \\
42.97 \pm 1.17^{\mathrm{a}} \\
44.00 \pm 0.40^{\mathrm{a}} \\
45.00 \pm 0.20^{\mathrm{a}}\end{array}$ & $\begin{array}{l}83.20 \pm 3.20^{\mathrm{a}} \\
87.50 \pm 2.07^{\mathrm{a}} \\
90.53 \pm 1.55^{\mathrm{a}} \\
92.43 \pm 1.76^{\mathrm{a}}\end{array}$ \\
\hline & $\mathrm{G}$ & $\begin{array}{l}15 \\
30 \\
60 \\
90\end{array}$ & $\begin{array}{l}12.03 \pm 0.45^{\mathrm{a}} \\
11.97 \pm 0.55^{\mathrm{a}} \\
12.97 \pm 1.06^{\mathrm{a}} \\
13.50 \pm 0.17^{\mathrm{a}}\end{array}$ & $\begin{array}{l}27.97 \pm 2.15^{\mathrm{a}} \\
31.00 \pm 2.49^{\mathrm{a}} \\
32.47 \pm 0.65^{\mathrm{a}} \\
33.53 \pm 0.58^{\mathrm{a}}\end{array}$ & $\begin{array}{l}36.50 \pm 2.26^{\mathrm{a}} \\
38.00 \pm 1.73^{\mathrm{a}} \\
39.00 \pm 0.17^{\mathrm{a}} \\
40.00 \pm 0.66^{\mathrm{a}}\end{array}$ & $\begin{array}{l}76.50 \pm 4.83^{\mathrm{a}} \\
80.97 \pm 4.69^{\mathrm{a}} \\
84.43 \pm 1.85^{\mathrm{a}} \\
87.03 \pm 1.38^{\mathrm{a}}\end{array}$ \\
\hline & $\mathrm{M}$ & $\begin{array}{l}15 \\
30 \\
60 \\
90\end{array}$ & $\begin{array}{l}12.47 \pm 1.46^{\mathrm{a}} \\
12.97 \pm 0.65^{\mathrm{a}} \\
13.03 \pm 0.68^{\mathrm{a}} \\
14.03 \pm 0.35^{\mathrm{a}}\end{array}$ & $\begin{array}{l}29.03 \pm 2.72^{\mathrm{a}} \\
32.00 \pm 2.63^{\mathrm{a}} \\
33.50 \pm 0.87^{\mathrm{a}} \\
34.03 \pm 0.64^{\mathrm{a}}\end{array}$ & $\begin{array}{l}37.00 \pm 2.33^{\mathrm{a}} \\
38.03 \pm 1.74^{\mathrm{a}} \\
40.03 \pm 1.36^{\mathrm{a}} \\
40.97 \pm 0.99^{\mathrm{a}}\end{array}$ & $\begin{array}{l}78.50 \pm 6.44^{\mathrm{a}} \\
83.00 \pm 4.97^{\mathrm{a}} \\
86.57 \pm 2.77^{\mathrm{a}} \\
89.03 \pm 1.86^{\mathrm{a}}\end{array}$ \\
\hline
\end{tabular}

C: cows' milk

G: goats' milk

M: mixture of C\&G (1:1)

$\mathrm{a}, \mathrm{b}$ and $\mathrm{c}:$ means within the same column within each item with different superscripts are significantly different $(\mathrm{P} \leq 0.01)$.

\section{REFERENCES}

Awad, A.A. 2001. Some physico-chemical properties of ultrafiltrated milk and stability of some aggregation systems of casein. Egyptian J.Dairy Sci., 29: 77-85.

Ayesh, A.M.; Amera, H.A., Abou-Arab, A.A. \& Nagiub, K.H. 1995. Detection and determination of eight biogenic amines in frozen Mackerel (Scombromorous sp.) and Sardine (Sardinella sp.) using HPLC. J. Egypt. Ger. Soc. Zool., 17: 121-135.

Duncan, D.B. 1955. Multiple range and multiple f- tests. Biometrics 11: 1- 42.

Egyptian Organization for Standardization and Quality Control 1998. Semi- hard cheese, part 3: Edam cheese, ES: 1183, I.C.S: 67. 100. 30.

El-Abd, M.M; El-Batawy, M.A.; Younes, N.A. \& El-Tawel, H.S. 1992. Utilization of goats' milk in making RAS cheese. Egyptian J. Dairy Sci., 20: 91-100.

El-Batawy, M.A.; El-Abd, M.M.; Younes, N.A. \& El-Tawel, H.S. 1992. Effect of salting method on the ripening of Ras cheese made from mixed goats' and cows' milk. Egyptian J. Dairy Sci., 20: 341-350.

El-Demerdash,M.S. 1996. Studies on Gouda Cheese. M. Sc. Thesis, Fac. of Agric., Zagazig. Univ., Egypt.

El-Neshawy, A.A., El-Shafie, N.N. \& Abdel Baky, M.A. 1995. Utilization of ultra filtrated milk in the production of Edam-like cheese. Zagazig J. Agric. Res. 22: 775-787.

El-Sheikh, M.M., Farrag, A.F., Al-Khamy, A.F. \& El-Shibiny, S. 1999. Edam cheese from low whey proteins milk retentate. Egyptian J. Dairy Sci., 27: 317-329.

El-Shibiny, S., Al-Khamy, A.F., Shahein, N.M. \& El-Sheikh, M.M 1998. Effect of sodium caseinate addition on yield and quality of Edam cheese made by ultrafiltration. Egyptian J. of Dairy Sci., 26: 117 - 130.

El-Shobery, M.A. 1988. Molecular hysteresis of the poteniometric Acid- base titration as a control method of cheese ripening. Egyptian J. Dairy Sci., 16: 89 - 97.

El-Sisey, S.A. 2002. Studies on Semi-hard Cheese. Ph.D. Thesis, Fac. of Agric. Menofiya Univ., Egypt. 
Fikry, A. S. A. 1978. Chemical and Bacteriological Studies on Edam Cheese. M.Sc. Thesis, Fac. of Agric. Cairo Univ., Egypt.

F.B.S. 1998 . Food balance sheet. Ministry of Agriculture and Land Reclamation. Economic Affairs Sector (EAS). Agricultural Economic Resources. Egypt.

F.B.S. 2002. Food balance sheet. Ministry of Agriculture and Land Reclamation. Economic Affairs Sector (EAS). Agricultural Economic Resources. Egypt.

Ganguli, N.C. 1973. State of casein micelle in buffalos' milk. Neth. Milk Dairy J., 27: 258 -270 .

Hiekal, A.H., Kandeal, A.A. \& Shendy, A.M. 1992. Relationship between type of milk and free fatty acid content of Ras cheese. Egyptian J. Dairy Sci., 20: 53-65.

IDF 2000. World Dairy Situation. Bull. Inter. Dairy Fedration Bull.No 355.

Ismail, A.M. 1995. Studies on Edam-like Cheese. M.Sc. Thesis, Fac. of Agric. Zagazig Univ., Egypt.

Joosten,H.M. 1987. Condition allowing the formation of biogenic amines in cheese. 3 factors influencing the amounts formed. Neth. Milk Dairy J. 41: 329- 357.

Kandeal, A.A., Nasr, M.M. \& Heikal, A.H. 1990. Chemical and electrophoretic studies on Ras cheese made from cows' milk by using flavour CP preparation. Egyptian J. Appl. Sci. 5: $45-61$.

Kosikowski, F.V. 1978. Cheese and Fermented Milk Foods. $2^{\text {nd }}$ printing with revisions (1982) 573. F.V. Kosikowski and Associates, P.O.B., 139 Brooktondale, Ithaca, New York, U.S.A .

Ling, E.R. 1963. A Text Book of Dairy Chemistry. Vol. II 3rd Chapman \& Hall Ltd., London.

McCullough, S.W.F. 2003. Nutritional evaluation of goats' milk. British Food J., 105: 239251.

Mehanna, N.M., Antila, P. \& Pahkala, E. 1989. High performance liquid chromatog-raphic analysis of biogenic amines in Egyptian cheeses. Egyptian J. Dairy Sci., 17: 19-26.

Naguib, K.H, Ayesh, A.M. \& Shalaby, A.R. 1995. Studies on the determination of biogenic amines in foods. 1. Development of a TLC method for the determination of eight biogenic amines in fish. J. Agric. Food Chem. 13: 134 - 139.

Nasr, M.M., El-Sayed, M.M. \& El-Samrgy, Y.A. 1991. Acceleration of Edam cheese ripening using acid fungal protease. Nahrung $\mathbf{3 5}$ : $143-148$.
Nasr, M.M., Youssef, L.M. \& Kandeal, A.A. 1992. Accelerated of Edam cheese ripening with flavour AGECP enzyme preparation added to cheese curd. Egyptian J. Food Sci., 20 : 285-293.

Ramos, M., Fontech, J., Juarez, M., Amigo, L., Mahfouz, M.B. \& El-Shibiny. S. 1988. Total and free fatty acids composition and protein fractions of market Domiati cheese. Egyptian J. Dairy Sci., 16: 165- 174.

Rao,K. H. 1990. Ph.D. Thesis, NDRI (Deemed University), Karnal, India. (C.F. Singh.S, Rao, K.H. \& Kanawjia, S.K. 1992. Goat milk products technology - a Review. Indian J. Dairy Sci., 45: 572-587).

Rodriguez, S.N, Veciana-Nogues, M.T., RoigSoguest, A.X., Trujillo-Mesa, A.J. \& Vidal-Carou, M.C. 2002. Influence of starter and non starter on the formation of biogenic amines in goat cheese during ripening . Journal of Dairy Sci., 85 : 24712478 .

Scott, R. 1998. Cheese Making Practice. Applied Science Publ. LTD .Third edition, PP. 372 -374, London, UK .

Shahin, Y. 1977. Contents of Raw Milk Free Fatty Acids in Respect Production Factories. Ph.D.Thesis, Justus-Liebig. Univ. Giessen, W. Germany.

Shendy, A.M. 1989. Studies on Goats' Milk Utilization in Soft and Hard Cheese Making. Ph.D. Thesis, Fac. of Agric., Al-Azhar Univ., Egypt .

Shendy, A.M., Hiekal, A.H. \& Neamat-Alah, A.A. 1993. Evaluation of adding flavour Age CP preparation on Ras cheese properties made from a mixture of goats' and cows' milk. Egyptian J. Dairy Sci., 21: 8996.

SPSS 1998. Statistical Package for Social Sciences. Version 8. SPSS Inc.

Stahli, S.1965. Thin layer Chromatography. pp. 149.Academic Press, New York and London 1965.

Tawfik, N.F., Shalaby, A.R. \& Effat, B.A. 1992. Biogenic amines of Ras cheese and incidence of their bacterial producers. Egyptian J. of Dairy Sci., 20 : 219-225.

Taylor, S.I. 1985. Histamine poisoning associated with fish, cheese and other foods. World health Organization WPH/FOS, 85: 1-47. (C.F. International J. Food Microbiology 2000, 58: 1-37.

Zaki, N. \& Salem, S.A. 1992. Effect of proteolytic enzymes as accelerated ripening of Edam cheese. Indian J. Dairy Sci., 45: 303-312. 


\section{استخلام لبن الماعز فى صناعة مشابه الجبن الأيلام}

وداد عزب مترى '، محمد عواد الباوى'، مصطف عبد المنعم زيدان'، حمدىسيد محمد الطوليلr

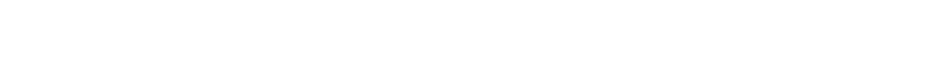

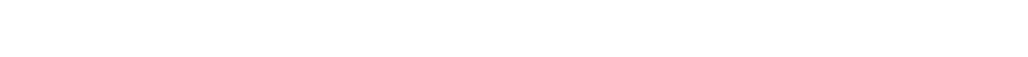

لستخم في البلاد الأوروبية مل فرنسا و إيطاليا وسويسرا لبن الماءز في تصنيع أنواع متميزة من الجن إلا أن جبن

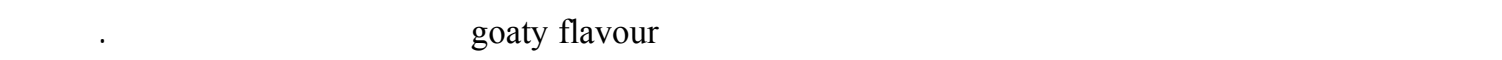

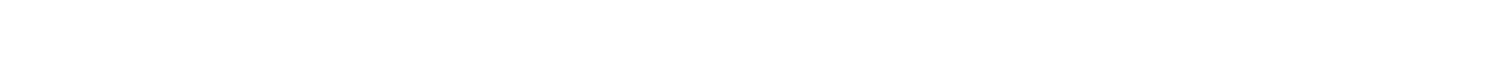

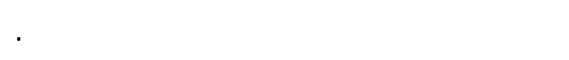

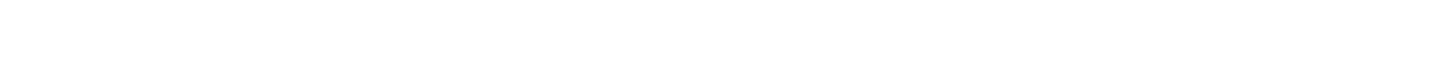

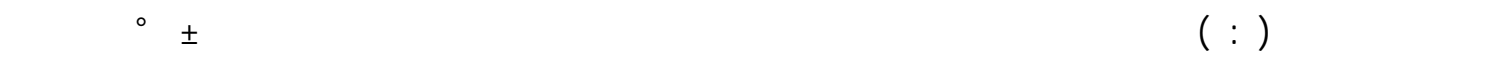

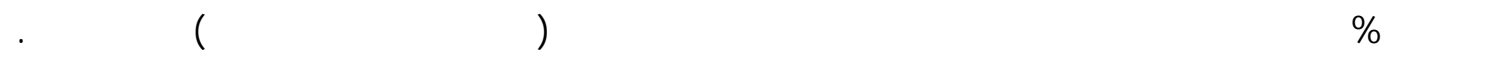
وقد لُٔلاهرت التنائج :

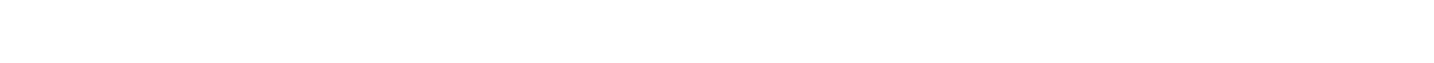

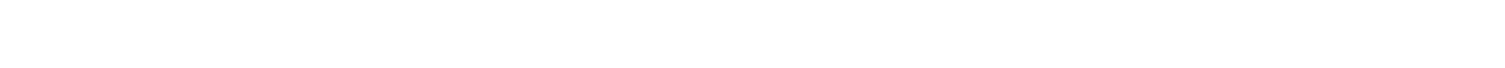

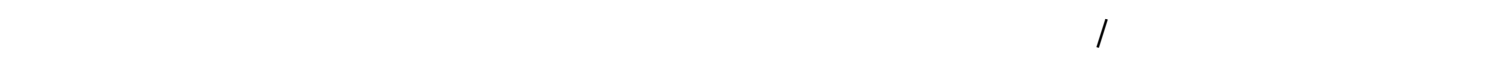

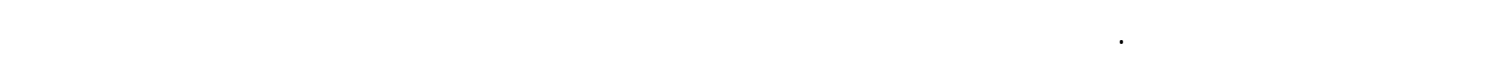

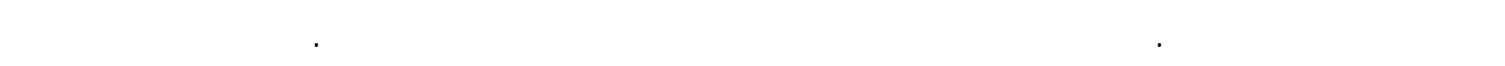

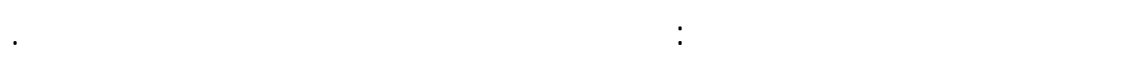

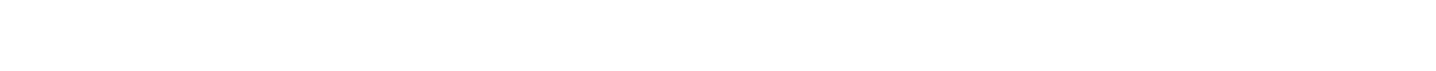

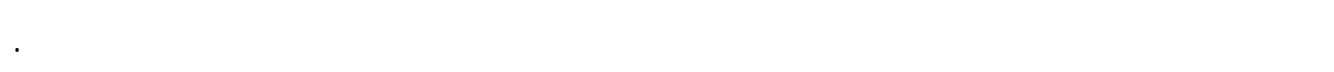

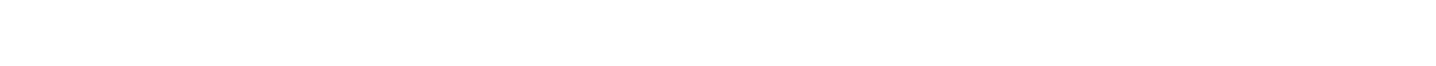

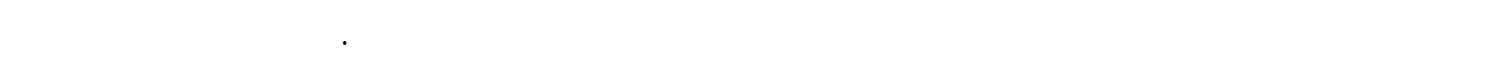

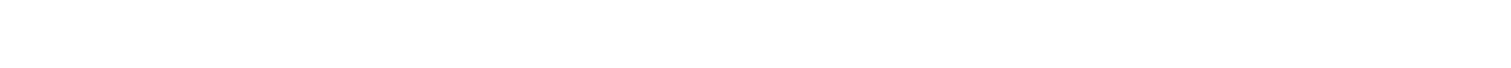

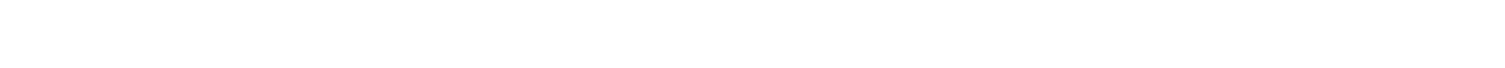

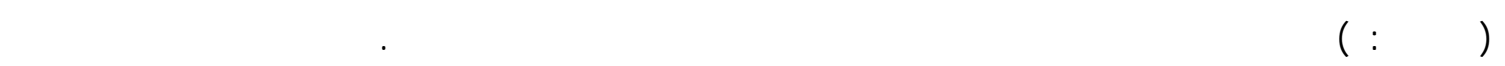

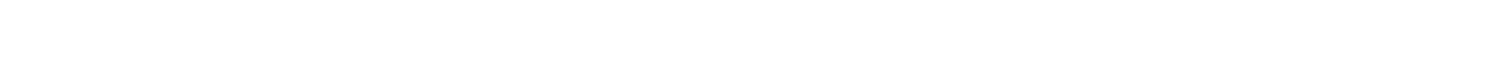

